$$
\begin{aligned}
& \text { ポーランド人類学の周辺 } \\
& \text { 佐 竹隆 } 1,2,3 * \\
& { }^{1} \text { 日本大学松戸歯学部 } \\
& 2 \text { 日本大学文理学部 } \\
& 3 \text { 国立健康 - 栄養研究所 }
\end{aligned}
$$

\title{
A periphery of the Physical Anthropology in Poland
}

\author{
Takashi Satake $e^{1,2,3 *}$ \\ ${ }^{1}$ Nihon University, School of Dentistry at Matsudo \\ ${ }^{2}$ Nihon University, College of Humanities and Sciences \\ ${ }^{3}$ National Institute of Health \& Nutrition
}

\begin{abstract}
要 約
Polish Academy of Sciences，Unit of Anthropology in Wroclaw に約 1 ヶ月滞在する機会があったので，Unit とポーランドの人類学に緾わるいくつかのことについて簡単に紹介したい。
\end{abstract}

\section{はじめに}

Polish Academy of Sciences (PAS) [Poliska Akademia Nauk (PAN) ] の Dr. Sławomir Kozieł (Director of the Unit of Anthropology in Wroclaw) を2013 年初めて訪衩た時, Unitは Wrocław の街の中心の非常に良い場所にあり， PAS の博物館も骨庫も近接していた。現在は前より鄙び た場所に移動し, 元の場所は The University of Wroclaw になった。博物館は University に帰属することになり元 通りであるが, 骨庫は新しい場所を探しているところで, 骨標本（2000 余個）の移動は未だ完了していない。

ここでは, Polish Anthropological Society, Polish Academy of Sciences (Unit of Anthropology in Wroclaw), 青少年 の人類学的調査の報告書「Anthropologiczne badania dzieci i młodzieży w Polsce w latach 1966-2012 Zmiany sekularne i zróznicowanie społeczne」（Kozieł et al., 2014）を中心に,
ポーランドの人類学を紹介したい。題名を「ポーランド 人類学の周辺」としたのは, 多くの資料や書物を参考 にして書いたわけではなく, 前述の調査報告書と PAS での日々の会話から得た情報を中心に纏めたからで ある。

\section{Polish Anthropological Society}

Polish Anthropological Society の会員数は未確認情報で あるが約 300 余名, 発育研究（Auxology）を専門とする ものは 20 名位であろらとのことであった。現在会長は Prof. Maria Kaczmarek (Adam Mickiewicz University) で, 2015年9月 16 日〜 18 日まで45th Biannual Scientific Conference of the Polish Anthropological Society が Poznan で開 催された。2010 年の EAA（European Anthropology Association）（佐竹, 2008）の学会も Prof. Kaczmarek を大会長 に Poznań で行われた。今回の Conference はポーランド

*日本大学松戸歯学部

干271-8587 千葉県松戸市栄町西 2-870-1

E-mail: satake.takashi@nihon-u.ac.jp

(C)2015 The Anthropological Society of Nippon 
人類学会の 90 周年記念大会でもあり, そのキャッチ・ フレーズは "Facing Challenges of Human-Environment Interactions...”で，キーノート・レクチャーは，以下の演 者により行われた。

Prof. Nicholas C.G. Mascie-Taylor (Cambridge Univ. UK): Human-Environmental Interactions-the Double Burden of Malnutrition.

Prof. Charlotte Roberts (Durham Univ. UK): Palaeopathology and its Relevance to Understanding Health and Disease Today: The Impact of the Environment on Health Past and Present.

Prof. Robert M. Malina (Tarleton State Univ. USA): Human Biology Research in Oaxaca, Southern Mexico: Historical Overview.

Prof. Napoleon Wolański: Biodemographic Changes in Polish Population in the Past Seven Decades and Underlying Socio-Political Transformations.

一般演題は以下の分野に分けて行われた。

1) Biomedical Issues of Growth and Development

2) Biology of Past Human Populations

3) Biodemorgraphy

4) Advanced Techniques in Anthropological Research

5) Knanthropometry

6) Odontology

7) Trends over Time in Human Biology

8）その他

口頭発表は 56 題でポーランド人がほとんどで，他は チェコ，ベラルーシュ，スロバキアからの参加者があっ た。ポスター発表は 47 題でベストポスターには賞が与 えられた。口頭・ポスター発表とも殆どがポーランド語 で行われ，学会参加費は500PLNであった。Polish Anthropological Society は 1925 年 Prof. Adam Wrzosek に より設立された。その公式雑誌 Anthropological Review は英文で年二回発行され，（http://www.ptantropologiczne. $\mathrm{pl} / \mathrm{en} /$ ) で閲覧できる。年会費は 50PLN と学会参加費に 比べて安く，学会の運営について聞いてみると出版につ いは政府の補助を受けているとのことであった。

ポーランド国内の自然人類学に関してUnitは重要な役 割を担っているとのことであった。UnitのあるWrocław には，自然人類学に関する機関が 3 つる。PAS, The University of Wroclaw, The Wroclaw University of Environmental and Life Sciences で，それぞれ 10 名以上の研究者 がいる。The University of Wroclaw は Kraków にある Jagiellonian University についでポーランドで二番目に古い
大学で, 最近, Department of Anthropology は Department of Human Biology に改名された。

\section{Polish Academy of Sciences (PAS), Unit of Anthropology in Wroclaw}

Polish Academy of Sciences（PAS）は 1952 年設立され た国の科学研究機関の 1 つで（Strelau, 2005; Jamroz and Kalinowska, 2013, 2014), 当初よりトップの科学者による 多くの業績や委員会を通して科学的な忠告やアドバイス を行ら研究者集団である。PAS は Warszawaを中心に ポーランド国内に数箇所あり,さらに, Foreign Scientific Centers がイタリア，オーストリア，ドイッ，フランス， ベルギー，ロシアにある。PAS の組織構成はまず Divisionに分けられ，2005 年の時点で Division は I から VII まであり，Iは Social Sciences，II は Biological Sciences, III は Mathematical, Physical, and Chemical Sciences, IV は Technical Sciences, V は Agricultural, Forestry, and Veterinary Sciences, VI は Medical Sciences, VII は Earth and Mining Sciences であった。2014 年の時点で Division は I から Vまでになり，I は Humanities and Social Sciences, II は Biological and Agricultural Sciences, III は Mathematical, Physical, Chemistry and Earth Sciences, IV は Engineering Sciences，Vは Medical Sciencesに再編された。 各 Divisionの下には InstituteやUnit があり，人類学に関 する部門は Division II に属し，数年前までは Institute で あったが現在ではUnitに縮小された。さらに来年，再 編があるとのことで，Dr. Kozieł に更なる縮小かと尋ね たところ，人類学部門が発展するか否かはこれからの部 門の研究展開によると答えた。

PAS の研究者は研究の久が義務付けられている。現在, Unit of Anthropology には13 名の研究者が打り，それぞ れの専門分野は Growth and development, Biology of the past population, Osteology, Human Biology of Society など, 広くHuman Biology の分野をカバーしている。過去に Chairman of the Division of Biological Sciences of PAS で あった Prof. Tadeusz Bielicki（わたしがテキサス大学に 滞在した年, 氏はVisiting Professor として滞在）やProf. Barbara Hulanicka \& Institute of Anthropology に所属して いた。

これまでの Instituteから Unitにかけての人類学部門 の業績 (Strelau, 2005) は, 伝統的な人類学の研究やそ の応用，発育の個人差，就学前から成人に至る子どもの 発育や発育速度，成熟過程に遺伝的あるいは環境要因が いかに影響を与えるかを明らかにしたことや，また，男 
性の加齢の過程でホルモン（テストステロン, IGF-1, DHEA-S）の減少と関連のある症候を明らかにした。そ の症候は低階層でより多くみられ, さらに都市の 30 歳 から 60 歳の成人では学歴や職歴に関し地位が低くなれ ばなる注ど早死にの危険性が高くなることや婚姻の状況 によっても異なることを明らかにした。

Unit の出版図書について尋ねてみると, 以前, 雑誌 Studies in Physical Anthropologyを刊行していたが, 現在 は廃刊になったとのことであった。そらいえば初回訪ね た時，日本の国立科学博物館の紀要を図書室で見ること ができた。

\section{Unit of Anthropolgoy in Wroclaw の最近の業績}

最近の業績の一つを紹介したい。それは Institute 時代 から現在のUnitに至る人類学部門が，過去約 60 年間に 渡りポーラドの青少年の人類学的調査を主催し， 2014 年その調査結果を Dr. Kozieł が中心になり纏めた。その 報告書である冊子（Kozieł et al., 2014）はポーランド語 で書かれ，題名を英訳すると「Anthropological Survey of Children and Youth in Poland between 1966 and 2012, Secular Changes and Social Variation」となる。各章末に英語 の要約があるのでそこを中心に読み，分からないところ は著者らに尋ね以下のように要約した。

ポーラドの青少年の人類学的調査は 5 期にわたり行わ れた。それは，I期（1955 年～1959年)，II 期（1966 年〜 1969 年), III 期（1977 年～1978 年), IV 期（1987 年〜 1988 年), V 期（2012 年〜2014 年）で，それぞれポー ランドの幾つかの City, Town, Village で調査が行われた。 III 〜 IV 期は， Prof. Bielicki や Prof. Hulanicka が，V 期は Dr. Kozieł が主催した。それらは横断的調査で, 青少年 の身体計測 (身長, 体重, 上腕やウエストの周囲径など） や初経年齢,「居住地」(City, Town, Village),「家族数」 (子どもの数が 1 人， 2 人， 3 人かそれ以上),「両親の学 歴」（大学卒, 高校卒, 職業学校卒, 小学校卒) など社 会的要因に関する調査が行われた。

今回の報告は, II 期から V 期の 7 歳から 18 歳の 69,843 名についての横断的解析結果である。調査対象者 には，第二次大戦後の共産主義やその後の自由主義の時 代，またその移行期に生まれた者が含まれる。ポーラン ドには日本の学校保健統計調査報告書のよらなものはな $く$, この冊子 (National Science Center in Poland の援助に より出版）がポーランドの子どもの身体発育の状況を示 すことになるのであろら。

\section{I 身長, 体格指数 (BMI) の年次推移（1966 年から 2012 年)}

ポーランドは共産主義から自由主義に政治的に大きく 変わつたヨーロッパの国の 1 つで, 劇的な生活環境の変 化を経験した。そこでまず，子どもの身長など体格の年 次推移（時代変化）を分析した。II 期，III 期，IV 期， $\mathrm{V}$ 期の 4 期にわたる資料から，身長と BMI の年次推移 を分析すると, II 期と $\mathrm{V}$ 期の間に身長, BMI 共に有意 な年次推移がみられた（ただし，女子の 14 歳〜18 歳の BMI にはみられなかった)。身長の年次推移は，IV 期か ら V 期の変化より II 期から III 期の変化が大きく, 一方, BMI は II 期から III 期の変化より IV 期から V 期の変化 が大きかった。ポーランドの子ぞもの身長の年次推移は まだ続いているが，ここ10 年との速度は他の西欧諸国 と同様低下している。一方， BMI（思春期後期の女子を 除いて）は, 共産主義から自由主義に移行して大きくなっ た。これは，社会経済状況の変化に伴ら食糧事情の変化 や，身体活動量の減少と関係していると考兄られた。一 方, 思春期後期の女子に BMI の年次推移がみられなかっ たのは，1989年に始まる政治の変革に伴ら生活文化環 境の変化が，女子の瘦身への憧れや西欧型の美の追求を 助長することになり，食事摂取量の自己制限などがその 理由の一つとして考光られた。いずれにしても身体の大 きさは, その年次推移から生活環境の変化と関係するこ とが確認された。

\section{II 身長, 体格指数 (BMI) の社会階層による変化}

ここ 50 年の経済的, 社会的変化を II 期から V 期の「居 住地」,「家族数」,「両親の学歴」などの社会的要因をパ ラメーターとし，子ぞもの身長やBMI に及ぼすそれら の影響を考察した。「両親の学歴」に関して，父親の学 歴は女子の BMI には影響を与えないが，男女の身長に は有意な影響を与えた。一般的に，II 期，III 期，IV 期 では，City・子どもの数 1 人・両親が大学卒の全ての子 ぞもは，Village・大家族・小学卒の両親の子どもより高 身長で BMI も大きかった。しかし，V 期では男女の身 長で社会的要因の影響は減少した。すなわち，「家族数」 と「両親の学歴」では有意差はあるが（女子を除いて）, 「居住地」のCityと Village では有意差がなくなった。V 期の BMI に関しては，「家族数」以外の社会的要因の影 響は両性でなくなった。結論として，社会的要因の生物 学的指標 (身長, 体格指数) への影響は, II 期から $\mathrm{V}$ 期で「家族数」は男女の身長, BMI に影響はあるが，「居 住地」,「両親の学歴」の影響は減少した。子どもの身長, 
体重の発育は社会的要因に影響され, それらは社会環境 を反映する生物学的指標であることが再確認された。

\section{III 過体重, 肥満, 瘦身の割合の年次推移}

以上のように，身体の大きさの年次推移は生活環境の 改善と密接な関係のあることが確認された。さらに, ポーランドの子どもの過体重，肥満，瘦身の割合を IOTF (International Obesity Task Force) の cut-offs を用い て年齢ごとに算出し，II 期から V 期のそれらの割合の 変化をみると, まず, 過体重の割合の増加傾向がみられ た。すなわち，II 期と V 期の間で男子で $5 \sim 7$ 倍，女 子で $3 \sim 4$ 倍に増加した。そして, 劇的な変化は肥満の 割合についてで, 男子で 13 倍, 女子でほぼ 15 倍増加し た。ほとんどの調査で, 肥満の割合の最高值は男女とも 年少の子どもにみられ, その最高值は $\mathrm{V}$ 期の 7 歳の女 子 $(6.3 \%)$ で，それは II 期の 7 歳の女子 $(0.26 \%)$ の 24 倍以上である。 IV 期と V 期の間で思春期後期の女子 では過体重の割合は少し低下したが，肥満の割合は 2 倍 に増加した。 $\mathrm{V}$ 期の思春期後期の男子の過体重の割合, 肥満の割合は女子より 2 倍大きかった。瘦身の割合に関 して，III 期から V 期の間で男子は全年齢でコンスタン トに低下し，女子は II 期から V 期の間で思春期早期ま ではコンスタントに低下した。女子の最大值が出現する のは II 期である（全年齢の平均 $17.33 \%$ )。一方, 最低值 （男子 $5.74 \%$ ，女子 $10.00 \%$ ）はV 期にみられるが，思春 期後期の女子では IV 期と V 期の間でその割合は $8.96 \%$ から $11.29 \%$ に有意に増加した。

結論として, 青少年の肥満や過体重の増加は世界的に 深刻な問題である。ポーランドの子どもの肥満の割合の 増加は特に年少の子どもで夕られた。過剩な脂肪組織は 多くの健康の危険因子と関係があり, 成人の疾病や死亡 原因とも関係があり健康にとって脅威である。思春期後 期にみられる肥満や瘦身の割合の男女差の解釈として, 政策変化後にみられるよらになった女子の瘦身への憧れ や西欧型の美の追求が考光られた。

\section{IV 上腕囲, ウエスト・ヒップ比の年次推移}

身体の年次推移は, 以上のように有用な生活環境の変 化の指標であることが確認された。また, 上腕周囲径 (MUAC) は栄養状態の指標, ウエスト・ヒップ比 (WHtR) は脂肪の体内分布の指標之考光られて颃り, この50年 間の生活環境の変化と MUAS, WHtR の II 期から V 期 の年次推移をみると, 調査者数 64,703 名の MUAC と 64,624 名の WHtR から, 男子では MUAC, WHtR とも 7
歳から 18 歳までの全て, 女子では MUAC は7 歳から 14 歳まで, WHtR 8 歳から 13 歳までそれぞれ有意な 年次推移がみられた。MUACの最も増加したのはIV 期 と V 期の間で, 一方, WHtR の最も増加したのは男女 の 16 歳から 18 歳を除いて II 期と III 期の間で，16 歳か ら 18 歳は IV 期と V 期の間で最も増加した。III 期と IV 期の間では MUAC, WHtR ともに全ての年齢で男女と も有意な変化はなかった。

研究結果として, ポーランドの社会経済の変化が MUAC, WHtR に影響を与えていることが明らかになっ た。IV 期から V 期の間に自由主義経済の発展があり, 生活環境が大きく変わり食習慣の变化や身体活動量の減 少が男女の MUAC の増加と, 16 歳から 18 歳の男女の WHtR の増加に影響を与えたと考学られる。III 期と IV 期の間で，男女とも MUAC，WHtR に葟とど有意な 変化がみられなかったのは, 共産主義下の経済の停滞や 食糧不足によるものと考兄られる。以上, MUACや WHtR も社会経済の信頼できる生物学的指標であること や最近のポーランドの少年, 少女の過剩脂肪への年次推 移が明らかになった。

\section{$\vee$ 女子の初経年齢の年次推移と社会階層による差}

初経年齢は，特に，社会経済状態の影響を受け易い。 その中でも家族の影響は大きい。ポーランドの女子の II 期から V 期の初経年齢の年次推移と社会的要因の影響 を分析した。初経年齢の調査は, II 期, III 期, IV 期, $\mathrm{V}$ 期の 7 歳から 18 歳の 6,712 名を対象に行われ, 社会 的要因調查 (「居住地」, 「家族数」,「両親の学歴」) との 関連について分析が行われた。その結果, 初経年齢の急 激な若年化が II 期と III 期の間でみられた（13.79歳から 13.09 歳に早まった)。そして, IV 期では 13.26 歳と遅 くなり, 再び, $\mathrm{V}$ 期で 12.97 歳になった。この初経年齢 の変化のパターンは各社会階層で夕られた。初経年齢が 最も変化したのはV Village の子で, II 期から V 期の間で 14.11 歳から 13.11 歳に若年化した。同様に,「両親の学歴」 の影響を最も受けてきたのは小学校学歴の父親の子で, II 期で初経年齢は 13.95 歳と最も遅く, V 期では 12.99 歳と若年化し親の学歷の影響も減少した。「家族数」に 関して, 最も初経年齢が变化したのは 3 人以上の子ぞも の家族の子で，II 期から V 期の間で 14.06 歳から 13.35 歳に若年化した。初経年齢にも年次推移が夕られ, 自由 主義経済になり社会的要因の初経年齢への影響は少なく なり, その中でも「家族数」の影響が特に少なくなった。 


\section{VI まとめ}

社会的要因の調査項目間には高度な内部相関があり, 各々の項目の純粋な効果を分析することは難しいが，疑 万余地なく調查の行われた 46 年の間にポーランドは相 当な文化的躍進を遂げた。そして，25 年前の自由主義 経済への移行後, 全体的に社会経済状態は良くなり子ぞ もの発育環境も良くなり身長や体重の発育は保障され， 女子の性成熟は加速化し社会階層による差も少なくなっ た。これらの結果から, 現在, ポーランドは社会経済格 差により身体の生物学的差異の生じない社会へと歩んで いることが明らかになった。

\section{さいごに}

出かける直前，ポーランドに関する新刊本を検索し一 冊（小林，2015）持参した。街の中心にあるオペラ座の 近くに, 最近, 素晴らしい音楽ホール（National Forum of Music）が完成した（Tateo Nakajima 氏も建造に参画）。 柿落としの日，ホールへの道すがらの公園に持参した本 で読んだ主人公の真新しいモニュメントを偶然発見し た。真っ赤なバラが 1 輪供兄られていた。なんとも心に 染みる美しい光景であった。ポーランドの変革と躍進を そのモニュメントと音楽ホールは実感させてくれた。そ して，社会経済状況が身体発育の年次推移に与兄た影響 を明らかにした青少年の人類学的調査の結果を容易に受 け入れることができた。

ポーランド人は自国語に誇りを持っているのか, Wrocław の街の中で英語表記を見ることは非常に少な く，それは日本以上であった。しかし，最近，外国の観 光客の増加に伴い英語表記が増兄つつあるとのことで あった。日がな一日 Wrocław Główny（中央駅）で行き 交う人々を眺めていると，身長の非常に高い人，脚が非 常に長い人，顔の大きさが身体に比べ非常に小さい人な ぞ，そのバリエーションは非常に大きく感じられた。そ の事を Dr. Kozieł に話すと，いや，ポーランド人は英国
人やドイッ人と異なりバリエーションは小さく，日本人 と同様単一民族だと答えた。（当方にはそうは思觉ない が…。）ぞのように人の身体の集団差を確認するのか。 もちろ几数字により捉えることになるが，それは，身体 を代表するパラメーターであり，身体全体を想像する根 拠の一つではあるが全てではない。その違いは，実際に 見て，感じるしかない。人類学でいらフィールド調査の 重要さを示す例であろう。

最後に，調查報告書を理解する上で Drs. Aleksandra Gomula, Natalia Nowak-Szczepańska (The Unit of Anthropology in Wroclaw）には多大なる助けを受けた。Prof. Maria Kaczmarek (Adam Mickiewicz University) には, Polish Anthropological Society そついて，また，Dr. Kozieł（Director of the Unit of Anthropology in Wroclaw）には全般的にポー ランドの人類学に関する質問に答えてもらい, また, 日々 心地よく過ごせるょう Polish Academy of Sciences の人々 ともども配慮頂いた。Prof. Robert Malina（Taleton State University) には, Poland の Anthropology と Physical Educaitonの関係などについて教わった。以上の方々に深 甚の謝意を表します。

\section{参考文献}

Jamroz E. and Kalinowska K. (2013) Annual Report 2013. Polish Academy of Sciences, Office of Science Promotion.

Jamroz E. and Kalinowska K. (2014) Annual Report 2014. Polish Academy of Sciences, Office of Science Promotion.

小林公二 (2015) アウシュヴィッツを志願した男. 講談社, 東京.

Kozieł S., Nowak-Szczepańska N., and Gomula A. (2014) Anthropologiczne badania dzieci i młodzieży w Polsce w latach 1966-2012 Zmiany sekularne i zróznicowanie społeczne. Oficyna Wydawnicza Arboretum, Wrocław.

佐竹隆 (2008) ヨーロッパ人類学会. Anthropological Science (Japanese Series), 116: 71-76.

Strelau J. ed. (2005) Polish Academy of Sciences-The Past and the Present-. Drukarnia Narodowa S.A., Kraków. 